\title{
Treatment of Vitamin D Deficiency in Children and Adolescents
}

\author{
Arani KS $S^{*}$ Tehrani FM and Rezvani RS
}

\author{
Research Center for Biochemistry and Nutrition in Metabolic Disorders, Kashan University of Medical Sciences, \\ Kashan, Iran
}

${ }^{*}$ Corresponding author: Arani KS, Research Center for Biochemistry and Nutrition in Metabolic Disorders, Kashan University of Medical Sciences, Kashan, Iran, Tel: +98-3615550026, E-mail: kobra.shiasi@yahoo.com

Citation: Arani KS, Tehrani FM, Rezvani RS (2016) Treatment of Vitamin D Deficiency in Children and Adolescents. J Nutr Health Sci 3(1): 105. doi: 10.15744/2393-9060.3.105

Received Date: February 04, 2015 Accepted Date: February 22, 2016 Published Date: February 24, 2016

\begin{abstract}
Background \& Objective: Both high prevalence of poor vitamin D status and obesity in children and adolescents are known health problems, but there is not enough information about adequate dose of vitamin D to treat these children. The aim of this study is to evaluate the efficacy of an oral vitamin $\mathrm{D}$ regimen for this problem.

Material and Method: In this clinical trial 100 children and adolescents with vitamin D deficiency or insufficiency were participated. The vitamin D deficiency defined as $25 \mathrm{OHD} \leq 15 \mathrm{ng} / \mathrm{ml}$ and vitamin D insufficiency as $15 \leq 25 \mathrm{OHD} \leq 20 \mathrm{ng} / \mathrm{ml}$. In terms of obesity, individuals were classified in two groups: obese \& overweight (57 subjects) and normal weight (43 subjects). All subjects received 50000 IU vitamin D once a week for 6 weeks, and the 25OHD level was measured 2-6 months later.

Result: The mean $25 \mathrm{OHD}$ level before treatment in first group (obese \& overweight) was $10.74 \pm 5.96 \mathrm{ng} / \mathrm{ml}$ and in normal weight group was $10.81 \pm 5.41 \mathrm{ng} / \mathrm{ml}$. ( $\mathrm{P}=0.54)$ Average levels of $25 \mathrm{OHD}$ after initial treatment was $33.64 \pm 22.43 \mathrm{ng} / \mathrm{ml}$ and $37.66 \pm 17.74 \mathrm{ng} / \mathrm{ml}$ respectively $(\mathrm{P}=0.6)$ The frequency of vitamin $\mathrm{D}$ deficiency and insufficiency after initial treatment was $12.8 \%$ and $9.3 \%$ respectively.

Conclusions: This study showed that treatment with 50000 IU Vitamin D weekly for 6 week is a safe and effective regimen for majority of Vitamin D deficient or insufficient children regardless of obesity status.

Keywords: Vitamin D deficiency; Vitamin D insufficiency; Obesity; Children
\end{abstract}

\section{Introduction}

Vitamin D deficiency is a common health problem over the entire world and recognized as a pandemic $[1,2]$. Foods naturally contain very small amount of vitamin $\mathrm{D}$, and fortified foods with vitamin $\mathrm{D}$ are often inadequate to satisfy vitamin $\mathrm{D}$ requirements [2]. So the major cause of vitamin D deficiency is the inadequate sun exposure. In the recent years many reports have been published about the high prevalence of vitamin D deficiency in obese children and adolescents, also obesity epidemic between teens is rising [3-6]. A prospective study showed that serum 25 hydroxy-vitamin D (25OHD) level is inversely associated with the development of adiposity in children [7]. Severe vitamin D deficiency leads to myopathy, clinical rickets in children, and osteomalacia in adults $[8,9]$. In addition to musculoskeletal effects, vitamin $\mathrm{D}$ is also important for immune system performance , and vitamin D deficiency is probably linked with a variety of diseases including: hypertension, cancer, diabetes and multiple sclerosis $[8,10,11]$. The prevalence of vitamin D deficiency varies from $44.8 \%$ to $79.6 \%$ in Iran [12-14]. The vitamin D level lower than $20 \mathrm{ng} / \mathrm{ml}$ is associated with decrease in the function of pancreatic cells and lower insulin sensitivity [15]. The correction of vitamin D level can increase the insulin sensitivity in obese children [16,17]. The serum 25OHD levels to a lesser extent or equal to $15 \mathrm{ng} / \mathrm{ml}$ has been suggested as the threshold for negative effects of vitamin D deficiency on the level of insulin sensitivity in obese African American girls [18]. The study of Weaver, et al. (2004) has shown that the $32 \mathrm{ng} / \mathrm{ml}$ serum level of $25 \mathrm{OHD}$ is required for the proper absorption of calcium and adequacy of the parathyroid hormone suppression [19]. However, there are insufficient data about the ideal vitamin D regimen to correct 25OHD level in healthy children and adolescents. Multiple therapeutic regimes have been introduced for this problem, each one has benefits and restrictions. Some of these vitamin D regimens are as follows: 50,000 IU weekly for 6-8 weeks [20], 50,000 IU weekly for 4 weeks then monthly for 5 months, 50,000 IU three times a week for 6 weeks [21], two doses of 100,000 IU vitamin D with the three-month interval [22]. The aim of this study is to evaluate the effect of an oral vitamin D regimen for treatment of vitamin D deficiency in obese children and adolescents.

\section{Materials and Methods}

\section{Participants and Study design}

This study was conducted as a before-after clinical trial on the obese and overweight children and adolescents with vitamin $\mathrm{D}$ deficiency or insufficiency between 2 to 18years old from june 2013until November 2014. The study design was approved by ethical 
committee of Kashan University of Medical Sciences and written consent was obtained from the parents of patients. All participants were examined by a pediatric endocrinologist. Exclusion criteria included the following: 1) recent use of vitamin D preparations (for last six months), 2) the disorders of the calcium, phosphorus and vitamin D metabolism, 3) the use of medication affecting vitamin D metabolism such as antiepileptics and estrogens, 4) malabsorbtion disorders such as celiac disease, cystic fibrosis, etc. 5) endocrine disorders such as cushing's disease, hypothyroidism, pseudohypoparathyroidism, etc. 6) any acute or chronic illness, 7) the use of alcohol or tobacco.

\section{Anthropometric measurements}

The weight, height, body mass index (BMI) and pubertal stage were determined. BMI was calculated as weight (kg) divided by height $^{2}(\mathrm{~m})$. The subjects were divided upon BMI using the CDC (Centers for Disease Control and Prevention) growth charts to three groups: 1) Obese: BMI at or above the $95^{\text {th }}$ percentile for age and gender, 2) Overweight: BMI at or above the $85^{\text {th }}$ percentile and lower than $95^{\text {th }}$ percentile for age and gender, 3) Normal weight: BMI lower than $85^{\text {th }}$ percentile for age and gender [23]. BMISDS were calculated on the basis of 2000 normative data from the CDC.

\section{Serum Assay and Treatment Regimen}

Serum level of 25OHD level was measured using the chemiluminescence assay (DiaSorin, LIAISON ${ }^{\circledR} 25 \mathrm{OH}^{2} \mathrm{Vimin}^{\mathrm{D}}$ assay). Vitamin D deficiency was defined as a serum 25OHD level of $<15 \mathrm{ng} / \mathrm{ml}$ and vitamin D insufficiency as a 25OHD level of 15-20 $\mathrm{ng} / \mathrm{ml}$ [24,25]. Vitamin D sufficiency have been considered as serum $25 \mathrm{OHD}$ concentrations of $20 \mathrm{ng} / \mathrm{ml}$ or greater [24]. Subjects with vitamin D deficiency or insufficiency were treated with one pearl of vitamin D (50,000 IU) once a week for 6 weeks. Vitamin D3 pearls were provided by Alhavi Company Iran. A second blood sample for the measurement of 25OHD level was obtained 2-6 months later. This trial was registered in Iranian Registry of Clinical Trials (IRCT), No. IRCT2014090812421N2 .

\section{Statistical methods}

Statistical analysis was performed using SPSS, version 16.0 (SPSS software Inc, Chicago, IL, USA). Values of descriptive data were presented as mean \pm standard deviation. $\mathrm{P}$ values lesser than 0.05 (two-sided) were considered statistically significant. No imputations of missing data were made. Baseline characteristics of participants were compared using either independent $t$ tests (continuous) or chi-square tests (categorical). After treatment, changes between-group from baseline were analyzed repeatedmeasures ANOVA.

\section{Results}

From 328 children and adolescent with vitamin D deficiency or insufficiency who treated with vitamin D only 141 subjects came for second sampling (45 obese, 29 overweight, 67 normal weight). Some patients due to the difficulty in taking the pills, were treated by vitamin D injection, so they were excluded. Finally 101 children remain in the study (34 obese, 23 overweight and 43 normal weight). The mean age was $10.04 \pm 3$ years and the mean BMI was $21.18 \pm 3.96$. The subjects were classified into two groups: 1- obese and overweight (57 individuals) 2- normal weight (43 individuals). Two group have not significant difference in time of sampling $(\mathrm{P}=0.86)$. The average level of serum $25 \mathrm{OHD}$ was $10.74 \pm 5.96 \mathrm{ng} / \mathrm{ml}$ and $10.81 \pm 5.41 \mathrm{ng} / \mathrm{ml} \mathrm{respectively}(\mathrm{P}=0.54)$. The average level of $25(\mathrm{OH}) \mathrm{D}$ was $33.64 \pm 22.43 \mathrm{ng} / \mathrm{ml}$ and $37.66 \pm 17.74 \mathrm{ng} / \mathrm{ml}$ respectively after the first course of treatment $(\mathrm{P}=0.6)$. A significant difference was observed between the 25OHD level before and after treatment $(\mathrm{P}=0.02)$ (Table1). Both sex had similar response to treatment $(\mathrm{P}=0.45)$.

The mean difference between the serum 25OHD level before and after treatment, was $26.28 \pm 18.54$ in normal weight and $24.13 \pm 22.14 \mathrm{ng} / \mathrm{ml}$ in Obese \& overweight group respectively $(\mathrm{P}=0.355)$.

The mean difference between the serum 25OHD level was $25.87 \pm 20.3$ before and after treatment, however the relationship was not significant within weight groups $(\mathrm{P}=0.365)$ and sex $(\mathrm{P}=0.394)$. After initial treatment, the frequency of vitamin $\mathrm{D}$ deficiency and insufficiency was $12.8 \%$ and $9.3 \%$ respectively, and $77.9 \%$ had serum $25 \mathrm{OHD}$ level over than $20 \mathrm{ng} / \mathrm{ml}$.

\begin{tabular}{|c|c|c|c|c|c|c|}
\hline Weight groups & \multirow{2}{*}{ Sex } & \multicolumn{2}{|c|}{$\begin{array}{c}\text { 25OHD } \\
\text { (pretreatment) }\end{array}$} & \multicolumn{2}{|c|}{$\begin{array}{c}\text { 25OHD } \\
\text { (posttreatment) }\end{array}$} & \multirow{2}{*}{ P value } \\
\cline { 3 - 6 } & & $\mathbf{N}$ & mean \pm SD & N & mean \pm SD & \\
\hline Obese \& overweight & Male & 12 & $5.04 \pm 11.31$ & 12 & $29.24 \pm 38.69$ & \\
\cline { 2 - 6 } & Female & 26 & $5.25 \pm 9.32$ & 26 & $22.47 \pm 30.33$ & \multirow{2}{*}{$\mathbf{p}=\mathbf{0 . 0 2}$} \\
\cline { 2 - 6 } Normal weight & Male & 12 & $3.66 \pm 11.85$ & 12 & $13.6 \pm 36.45$ & \\
\cline { 2 - 6 } & Female & 26 & $6.31 \pm 10.31$ & 26 & $19.98 \pm 39.8$ & \\
\hline
\end{tabular}

Table 1: Comparison of the serum 25OHD before and after treatment in terms of weight groups and sex 


\section{The sustainability of the treatment}

To evaluate the duration of effect of this regimen, second measurement of serum 25OHD was done 2-6 months later. In those subjects that sampling was done before 75 days from treatment onset (mean 60 days), the mean serum 25OHD was $41.03 \pm 20.94$ $\mathrm{ng} / \mathrm{ml}$ and in group with sampling after $75^{\text {th }}$ day (mean 128 days) was $28.19 \pm 13.15 \mathrm{ng} / \mathrm{ml}$. $(\mathrm{P}<0.0001)$. The mean difference between second and first serum $25 \mathrm{OHD}$ level was $29.77 \pm 21.29$ before $75^{\text {th }}$ day and $19.55 \pm 12.89$ after $75^{\text {th }}$ day $(\mathrm{P}=0.007)($ Figure 1$)$

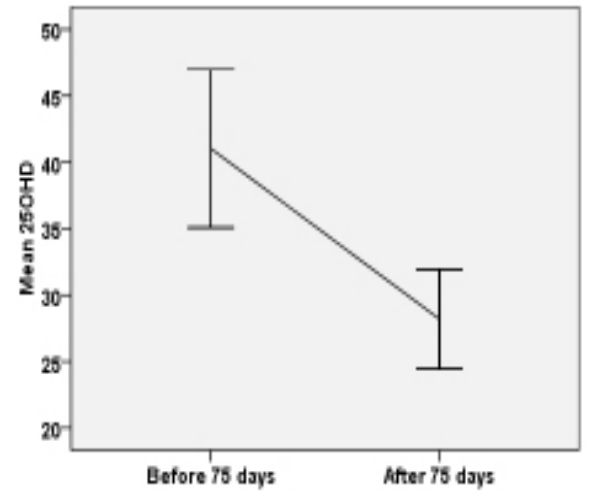

Figure 1: Comparison of 25OHD after treatment in terms of time

\section{Discussion}

Different definitions of vitamin D deficiency and insufficiency have been used in researches. Vitamin D deficiency was defined as serum $25 \mathrm{OHD}$ less than $15 \mathrm{ng} / \mathrm{mL}$ [24,26], less than $10 \mathrm{ng} / \mathrm{mL}$ [5,27] and less than $20 \mathrm{ng} / \mathrm{mL}[10,21,28]$. There is insufficient data about ideal regimen for treatment of vitamin D deficiency in children. Also there is controversy about response to treatment in obese children in comparison with other children. This study showed that obese children have similar response to treatment in comparison with normal weight children. We used the total dose of 300,000 units Vitamin D using 50000 IU Pearls weekly for 6 doses. This treatment causes the elimination of vitamin D deficiency or insufficiency in $77.9 \%$ of subjects $(25 \mathrm{OHD}>20 \mathrm{ng} / \mathrm{mL})$ and $53.9 \%$ of them achieved serum $25 \mathrm{OHD}$ over $30 \mathrm{ng} / \mathrm{mL}$. Our treatment method was similar to regimen that used by Harel, et al. (2011). They treated 43 vitamin D deficient obese children (25OHD less than $20 \mathrm{ng} / \mathrm{mL}$ ) aged 1-17 years with 50,000 IU of vitamin D once a week for 6-8 weeks, but only $28 \%$ of subjects achieved serum $25 \mathrm{OHD}$ over $30 \mathrm{ng} / \mathrm{mL}$ [20].

Another study that had similar results to our study has been performed by Malabanan, et al. They used 50,000 IU vitamin D once a week for 8 weeks and $60 \%$ of subjects achieved serum $25 \mathrm{OHD}$ over $30 \mathrm{ng} / \mathrm{ml}$ [29]. We did not find a significant difference between overweight or obese children with normal weight children in response to the above regimen but Rajakumar, et al. reported that obese children have less response to the treatment in 41 African -Americans children [30]. In a study in Argentina, 15 healthy 1018 years old teens with vitamin D deficiency, received two doses of 100,000 units of vitamin D with the three-month interval since the start of the winter, after the second dose, the $25 \mathrm{OHD}$ in all subjects reached to more than $15 \mathrm{ng} / \mathrm{ml}$ and none of the children had not 25OHD levels over than $50 \mathrm{ng} / \mathrm{ml}$ [31]. In a clinical trial in Yazd (Iran) 120 vitamin D deficient middle school aged girls received four different therapeutic regimen, those regimens starting with 300,000 units vitamin D and continuing with 50000 units monthly or1000000 units each three month have the best results [22].

In a medical center in Atlanta, Pepper, et al. evaluated three different regimens for vitamin D deficiency for 306 adult patients: 1) 50,000 units vitamin D once a week for four weeks and then monthly until 6 months. 2) 50,000 units vitamin D once a month for 3-6 months, 3) 50,000 units vitamin D three times a week for a period of 6 weeks. All three regimen increased 25OHD level but optimal levels of $25 \mathrm{OHD}$ (> $30 \mathrm{ng} / \mathrm{mL}$ ) achieved respectively $38 \%, 42 \%$ and $82 \%$ [21].

One of the important points in the treatment of vitamin D deficiency is sustainability of a treatment regimen. Our study has shown that serum 25OHD level had a drop after two months gradually, Harel, et al. also showed similar results [20] and this is against the injection of single-dose of 300,000 unit vitamin D that serum 25OHD level has a more gradual increase. Hashemipour, et al. (2005) was shown that serum 25OHD level after injection of single-dose of 300,000 unit vitamin D is increasing up to 4 months [32]. The level of serum 25OHD three months after intramuscular administration of 300000 units vitamin $\mathrm{D}$ was higher than previous determinations and was associated with increased serum levels of FGF-23 that accompanied by increasing the bone absorption [33].

Diamond, et al. showed that the effect of intramascular injection of $600000 \mathrm{IU}$ vitamin D to vitamin D deficient patients persist up to 12 months after treatment [34].

\section{Conclusions}

This study showed that the 50000 IU vitamin D weakly for six dose is a safe and effective regimen for treatment of vitamin D deficiency or insufficiency in children and adolescents. 


\section{Recommendation}

According to the results achieved in this study, we recommend to study the impact of 50000 IU vitamin D weakly for 8 weeks and then monthly for 6 months for treatment and prevention of recurrence of vitamin D deficiency or insufficiency in children and adolescents .

\section{References}

1. Hyppoenen E, Fararouiei M, Robertson C, Jarvelin MR (2007)Vitamin D and linear growth: cohort study on long term effects of rickets and large-dose supplementation. P Nutr Soc 66: 19A.

2. Holick MF, Chen TC (2008) Vitamin D deficiency: a worldwide problem with health consequences. Am J Clin Nutr 87: 1080S-6S.

3. Iyer P, Diamond F (2013) Detecting disorders of vitamin D deficiency in children: an update. Adv Pediatr 60: 89-106.

4. Kelishadi R, Haghdoost AA, Sadeghirad B, Khajehkazemi R (2013) Trend in the prevalence of obesity and overweight among Iranian children and adolescents: A systematic review and meta-analysis. Nutrition 30: 393-400.

5. Torun E, Gonullu E, Ozgen IT, Cindemir E, Oktem F (2013) Vitamin d deficiency and insufficiency in obese children and adolescents and its relationship with insulin resistance. Int J Endocrinol 631845.

6. Turer CB, Lin H, Flores G (2013) Prevalence of Vitamin D Deficiency Among Overweight and Obese US Children. Pediatrics 131: E152-61.

7. Gilbert-Diamond D, Baylin A, Mora-Plazas M, Marin C, Arsenault JE, et al. (2010) Vitamin D deficiency and anthropometric indicators of adiposity in schoolage children: a prospective study. Am J Clin Nutr 92: 1446-51.

8. Ward KA, Das G, Berry JL, Roberts SA, Rawer R, et al. (2009) Vitamin D status and muscle function in post-menarchal adolescent girls. J Clin Endocrinol Metab 94: 559-63.

9. Uush T (2013) Prevalence of classic signs and symptoms of rickets and vitamin D deficiency in Mongolian children and women. J Steroid Biochem Mol Biol 136: $207-10$.

10. Cheraghi N, Dai H, Raghuveer G (2012) Vitamin D deficiency is associated with atherosclerosis-promoting risk factor clustering but not vascular damage in children. Med Sci Monit 18: CR687-92.

11. Shroff R, Knott C, Gullett A, Wells D, Marks SD, et al. (2011) Vitamin D deficiency is associated with short stature and may influence blood pressure control in paediatric renal transplant recipients. Pediatr Nephrol 26: 2227-33.

12. Shakiba M, Nafei Z, Lotfi MH, Shajari A (2009) Prevalence of vitamin D deficiency among female students in secondary guidance school in Yazd city. Acta Medica Iranica 47: 209-14.

13. Moussavi M, Heidarpour R, Aminorroaya A, Pournaghshband Z, Amini M (2005) Prevalence of vitamin D deficiency in Isfahani high school students in 2004. Horm Res 64: 144-8.

14. Neyestani TR, Hajifaraji M, Omidvar N, Eshraghian MR, Shariatzadeh N, et al. (2012) High prevalence of vitamin D deficiency in school-age children in Tehran, 2008: a red alert. Public Health Nutr 15: 324-30.

15. Chiu KC, Chu A, Go VL, Saad MF (2004) Hypovitaminosis D is associated with insulin resistance and beta cell dysfunction. Am J Clin Nutr 79: 820-5.

16. Kelishadi R, Salek S, Salek M, Hashemipour M, Movahedian M (2014) Effects of vitamin D supplementation on insulin resistance and cardiometabolic risk factors in children with metabolic syndrome: a triple-masked controlled trial. J Pediatr 90: 28-34.

17. Belenchia M, Tosh AK, Hillman LS, Peterson CA (2013) Correcting vitamin D insufficiency improves insulin sensitivity in obese adolescents: a randomized controlled trial. Am J Clin Nutr 97: 774-81.

18. Ashraf A, Alvarez J, Saenz K, Gower B, McCormick K, et al. (2009) Threshold for effects of vitamin D deficiency on glucose metabolism in obese female African-American adolescents. J Clin Endocrinol Metab 94: 3200-6.

19. Weaver CM, Fleet JC (2004) Vitamin D requirements: Current and future. AmJ Clin Nutr 80: 1735S-9S.

20. Harel Z, Flanagan P, Forcier M, Harel D (2011) Low Vitamin D Status Among Obese Adolescents: Prevalence and Response to Treatment. J Adolesc Health 48: 448-52.

21. Pepper KJ, Judd SE, Nanes MS, Tangpricha V (2009) Evaluation of vitamin D repletion regimens to correct vitamin D status in adults. Endocr Pract 15: 95-103. 22. Shakinba MS, Tefagh S, Nafei Z (2011) The optimal dose of vitamin D in growing girls during academic years: A randomized trial. Turk J Med Sci 41: 33-7.

23. Schou AJ, Heuck C, Wolthers OD (2003) A randomized, controlled lower leg growth study of vitamin D supplementation to healthy children during the winter season. Ann Hum Biol 30: 214-9.

24. Andiran N, Celik N, Akca H, Dogan G (2012) Vitamin D deficiency in children and adolescents. J Clin Res Pediatr Endocrinol 4: 25-9.

25. Misra M, Pacaud D, Petryk A, Collett-Solberg PF, Kappy M, et al. (2008) Vitamin D deficiency in children and its management: review of current knowledge and recommendations. Pediatrics 122: 398-417.

26. Holmlund-Suila E, Koskivirta P, Metso T, Andersson S, Makitie O, et al. (2013) Vitamin D deficiency in children with a chronic illness-seasonal and age-related variations in serum 25-hydroxy Vitamin D concentrations. PLoS One 8: e60856.

27. Bowden SA, Robinson RF, Carr R, Mahan JD (2008) Prevalence of vitamin D deficiency and insufficiency in children with osteopenia or osteoporosis referred to a pediatric metabolic bone clinic. Pediatrics 121: e1585-90.

28. Roth CL, Elfers C, Kratz M, Hoofnagle AN (2011) Vitamin d deficiency in obese children and its relationship to insulin resistance and adipokines. J Obes 495101.

29. Malabanan A, Veronikis IE, Holick MF (1998) Redefining vitamin D insufficiency. Lancet 351: 805-6.

30. Rajakumar K, Fernstrom JD, Holick MF, Janosky JE, Greenspan SL (2008) Vitamin D status and response to Vitamin D(3) in obese vs. non-obese African American children. Obesity 16: 90-5.

31. Tau C, Ciriani V, Scaiola E, Acuna M (2007) Twice single doses of 100,000 IU of vitamin D in winter is adequate and safe for prevention of vitamin D deficiency in healthy children from Ushuaia, Tierra Del Fuego, Argentina. J Steroid Biochem Mol Biol 103: 651-4. 
32. Hashemipur S, Sarokhani M, Asefzadeh S, Mehrtash B, Sheikholeslami H, et al. (2008) Effect of Different Dosagse of Intramuscular Vitamin D3 on Serum 25(OH)D. Iranian J Endrocrin Metab 10: 115-20.

33. Turner C, Dalton N, Inaoui R, Fogelman I, Fraser WD, et al. (2013) Effect of a 300 000-IU Loading Dose of Ergocalciferol (Vitamin D-2) on Circulating 1,25(OH)(2)-Vitamin D and Fibroblast Growth Factor-23 (FGF-23) in Vitamin D Insufficiency. J Clin Endocrinol Metab 98: 550-6.

34. Diamond TH, Ho KW, Rohl PG, Meerkin M (2005) Annual intramuscular injection of a megadose of cholecalciferol for treatment of vitamin D deficiency: efficacy and safety data. Med J Aust 183: 10-2.

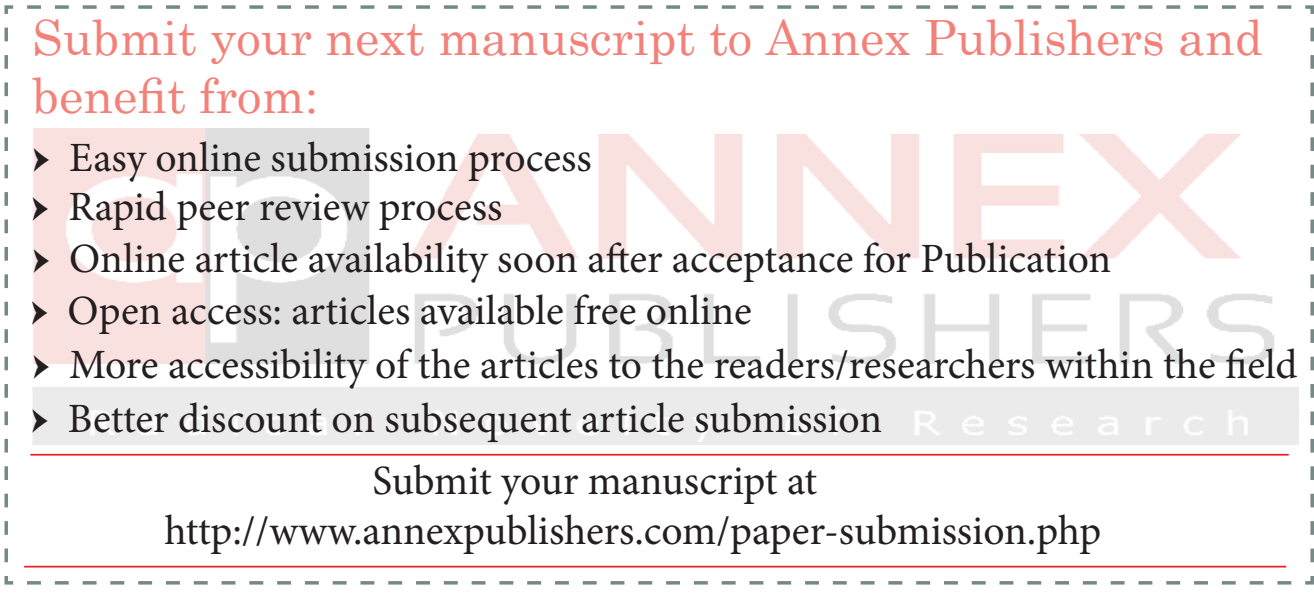

